\title{
Synthesis and characterization of mixed ligand complexes of $\mathrm{Zn}(\mathrm{II})$ and Co(II) with amino acids: Relevance to zinc binding sites in zinc fingers
}

\author{
P RABINDRA REDDY*, M RADHIKA and P MANJULA \\ Department of Chemistry, Osmania University, Hyderabad 500 007, India \\ e-mail: rabi_pr@rediffmail.com
}

MS received 5 October 2004; revised 21 February 2005

\begin{abstract}
Mixed ligand complexes of $\mathrm{Zn}(\mathrm{II})$ and $\mathrm{Co}(\mathrm{II})$ with cysteine, histidine, cysteinemethylester, and histidinemethylester have been synthesized and characterized by elemental analysis, conductivity, magnetic susceptibility measurements, and infrared, ${ }^{1} \mathrm{H}$ NMR, TGA and FAB mass spectra. In these complexes, histidine, and histidinemethylester act as bidentate ligands involving amino and imidazole nitrogens in metal coordination. Similarly, cysteine, and cysteinemethylester also act as bidentate ligands coordinating through thiol sulphur and amino nitrogen. Tetrahedral geometry has been proposed for $\mathrm{Zn}$ (II) and $\mathrm{Co}(\mathrm{II})$ complexes based on experimental evidence.
\end{abstract}

Keywords. Zinc; cysteine; histidine; histidinemethylester; cysteinemethylester.

\section{Introduction}

The amino acid, histidine, is the most frequently occurring ligand of zinc in the active centre of zinc containing enzymes. ${ }^{1}$ Both catalytic and structural zinc in enzymes are always coordinated by at least one cysteine and histidine donor. ${ }^{2,3}$ Of the metal ligating amino acids bearing $\mathrm{N}, \mathrm{O}$ and $\mathrm{S}$ containing donors in their side chains, cysteine and histidine are the most prominent ones for zinc. ${ }^{4,5}$ However, the importance of zinc for stabilization of protein loops in enzymes, zinc fingers etc., has generated new interest in the field of $\mathrm{Zn}$ coordination chemistry. ${ }^{6-12}$ The discovery of the 'zinc fingers' has triggered intensive research on the interaction of proteins with $\mathrm{Zn}$ ions. ${ }^{13-18}$ Zinc complex based units are present in a number of nucleic acid binding and gene regulatory proteins. ${ }^{19-22}$ The transcription factor III A, (TF III A) contains nine tandem repeats of the amino acid motif and each repeat has two invariant cysteines and two invariant histidines coordinated to $\mathrm{Zn}$ (Zn-finger) ${ }^{23-28}$ Since zinc is a crucial component of the tertiary structure of TF III A, wherein histidine and cysteine are coordinated to zinc in a tetrahedral configuration, we felt it was important to investigate the interactions of zinc with the corresponding amino acid residues in detail, as a model for the $\mathrm{Zn}$ core in TF III A. Since Co(II) ion has been used as an im-

\footnotetext{
*For correspondence
}

portant spectroscopic probe for proteins that have an $\mathrm{N}, \mathrm{S}$ (thiolate)-ligated metal centre, such as the ubiquitous zinc finger and blue copper proteins, ${ }^{29}$ this metal has also been included in this investigation. In our earlier publications, a detailed study regarding the interaction of zinc with histidine, cysteine, histidinemethylester, and cysteinemethylester by $\mathrm{pH}$ metry, ${ }^{1} \mathrm{H}$ and ${ }^{13} \mathrm{C}$ NMR spectroscopy are reported. ${ }^{30}$ Further, the factors responsible for the stability of zinc binding domains were assessed. The stability is due to favorable enthalpy and entropy contributions. In view of the importance of these studies, the present work was extended to isolation, characterization and purification of solid complexes involving $\mathrm{Zn}$ (II) and Co(II) different metal ions for a comprehensive understanding of binding sites in these systems.

\section{Experimental}

Cysteine (Cys), histidine (His), cysteinemethylester (Cysme) and histidinemethylester (Hisme) were obtained from the Sigma (USA). AnalaR grade zinc chloride, and cobalt chloride were obtained from EMerck. They were used as supplied.

\subsection{Synthesis of metal complexes}

The four complexes $[\mathrm{Zn}(\mathrm{Cys})(\mathrm{His})]^{-}(\mathbf{1}),[\mathrm{Co}(\mathrm{Cys})$ (His) $]^{-} \quad$ (2) $\quad[\mathrm{Zn}(\text { Cysme })(\text { Hisme })]^{+}$(3) and $[\mathrm{Co}$ 
$($ Cysme $)($ Hisme $)]^{+}(\mathbf{4})$ were synthesized by mixing an aqueous solution containing equimolar ratios of Cys (0.001 moles, $0.121 \mathrm{~g})$ and His (0.001 moles, $0.155 \mathrm{~g})$, Cysme $(0.001$ moles, $0.171 \mathrm{~g})$ and Hisme (0.001 moles, $0.242 \mathrm{~g}$ ), which were added simultaneously and independently to equimolar concentrations of zinc chloride, and cobalt chloride.

Stoichiometric ratios of metal and ligands are dissolved in aqueous medium and are refluxed until the complex is precipitated, and if not, the $\mathrm{pH}$ of the solution mixture is changed to precipitate the complex.

The synthesized complexes were found to be insoluble in the commonly known organic solvents. Consequently, the following physical measurements and analysis were carried out to check the purity and elucidate the structure. All the metal complexes are stable to air and moisture and decompose at very high temperatures.

\subsection{Elemental analysis and conductivity data}

Carbon, hydrogen and nitrogen analyses were obtained from the microanalytical Heraeus Carlo Etba 1108 elemental analyser. Chloride analysis was carried out by Mohrs method. The metal contents were estimated from these solutions on an atomic absorption spectrometer, Perkin-Elmer 23380. Conductivity of metal complexes was measured in freshly prepared DMSO solutions and obtained using a Digisun Digital conductivity bridge (model: DI-909) and a dip type cell calibrated with $\mathrm{KCl}$ solution.

\subsection{Spectral analysis}

2.3a IR spectra: The IR spectra were recorded (as $\mathrm{KBr}$ discs) on infrared spectrophotometers, Shimadzu IR-435, and Perkin-Elmer FTIR in the region $4000-400 \mathrm{~cm}^{-1}$.

2.3b ${ }^{l} H$ NMR spectra: Deuterated solutions of [Zn(Cys)(His)] and [ $\mathrm{Zn}($ Cysme $)($ Hisme $)]$ complexes were prepared in $99.8 \%$ of $\mathrm{D}_{2} \mathrm{O}$. The $\mathrm{pH}$ of the solution was maintained at 5-6 by adding $\mathrm{DCl}$ solution. ${ }^{1} \mathrm{H}$ NMR spectra were recorded for the above complexes of concentration $5 \times 10^{-2} \mathrm{~mol} \mathrm{dm}^{-3}$ at room temperature on a Varian Gemini $200 / \mathrm{MHz}$ pulsed FT NMR spectrometer. TMS was used as the internal standard. The ${ }^{1} \mathrm{H}$ NMR spectra for other complexes could not be carried out due to the low solubility of the complexes. 2.3c Reflectance spectra: Reflectance spectra of the complexes were recorded (in $\mathrm{KBr}$ discs) on a Shimadzu UV-160 spectrophotometer.

2.3d Magnetic susceptibilities: Magnetic susceptabilities of cobalt complexes were recorded at room temperature on a Faraday balance (CAHN-7600) using $\mathrm{Hg}\left[\mathrm{Co}(\mathrm{CNS})_{4}\right]$ as the standard. Diamagnetic corrections were made by using Pascal's constants. ${ }^{31}$

2.3e FAB mass spectra: FAB mass spectra of the complexes were recorded using a JEOL SX-120 instrument.

\subsection{Thermogravimetric analysis}

The absence of coordinated water was established for $\mathrm{Zn}$ (II) and $\mathrm{Co}$ (II) complexes by thermogravimetric analysis (TGA). TGA was carried out on a PerkinElmer model TGS-2 instrument.

\section{Results and discussion}

Analytical data corresponding to the 1, 2, 3 and 4 complexes are compiled in table 1 . It may be seen from the table that the complexes are in equimolar stoichiometric $1: 1: 1$ ratio. The presence or absence of chloride ions in the above complexes was determined by Mohr's method. No evidence was found for the presence of chloride ions in the coordination sphere of the complexes. The conductivity values (table 1) in DMSO correspond to non electrolytes for the complexes. ${ }^{32}$

\subsection{IR spectra}

The aminoacids (His and Cys) exist as zwitterions both in solution and in solid state. The IR spectra of amino acids exhibited significant features in $\mathrm{vNH}_{3}^{+}$ $\mathrm{vCOO}^{-}$regions. ${ }^{33}$ In histidine (table 2 ) the peaks at $3130 \mathrm{~cm}^{-1}, 3009 \mathrm{~cm}^{-1}$ were assigned to $\mathrm{vN}-\mathrm{H}$ asymmetric and symmetric stretching vibrations. The peak at $2877.3 \mathrm{~cm}^{-1}$ was assigned to $\mathrm{vC}-\mathrm{H}$ stretching frequency. The asymmetric and symmetric stretching vibrations of carboxylate group of histidine were observed at $1588 \mathrm{~cm}^{-1}$ and $1413 \mathrm{~cm}^{-1}$, the peak due to $v$ imidazole in-plane was observed at $\sim 964 \mathrm{~cm}^{-1}$. $\mathrm{NH}_{3}^{+}$twisting and rocking and $\mathrm{COO}^{-}$wagging frequencies were observed in the range $1200-600 \mathrm{~cm}^{-1}$. In cysteine (table 2), the peaks at $3000 \mathrm{~cm}^{-1}$ and 
Table 1. Analytical, conductivity and magnetic data of mixed ligand complexes of $\mathrm{Zn}$ (II) and Co(II) with cysteine, histidine and cysteinemethyl ester, histidinemethyl ester.

\begin{tabular}{|c|c|c|c|c|c|c|}
\hline \multirow[b]{2}{*}{ Complex } & \multicolumn{4}{|c|}{ Found (Calcd) (\%) } & \multirow{2}{*}{$\begin{array}{c}\lambda_{\mathrm{M}} \mathrm{Ohm}^{-1} \mathrm{~cm}^{-1} \mathrm{~mol}^{-1} \\
\quad \text { (in DMSO) }\end{array}$} & \multirow{2}{*}{$\begin{array}{l}\mu_{\text {eff }} \text { (B.M.) } \\
\text { (Temp. K) }\end{array}$} \\
\hline & Carbon & Hydrogen & Nitrogen & Metal & & \\
\hline $\begin{array}{l}{[\mathrm{Zn}(\mathrm{Cys})(\mathrm{His})]} \\
{\left[\mathrm{ZnC}_{9} \mathrm{H}_{13} \mathrm{~N}_{4} \mathrm{O}_{4} \mathrm{~S}\right]}\end{array}$ & $\begin{array}{c}31 \cdot 88 \\
(31 \cdot 91)\end{array}$ & $\begin{array}{c}3 \cdot 80 \\
(3 \cdot 84)\end{array}$ & $\begin{array}{l}16 \cdot 50 \\
(16 \cdot 54)\end{array}$ & $\begin{array}{l}19 \cdot 28 \\
(19 \cdot 32)\end{array}$ & 14 & Diamagnetic \\
\hline $\begin{array}{l}{[\mathrm{Co}(\mathrm{Cys})(\mathrm{His})]} \\
{\left[\mathrm{CoC}_{9} \mathrm{H}_{13} \mathrm{~N}_{4} \mathrm{O}_{4} \mathrm{~S}\right]}\end{array}$ & $\begin{array}{c}32 \cdot 50 \\
(32 \cdot 53)\end{array}$ & $\begin{array}{c}3 \cdot 87 \\
(3 \cdot 91)\end{array}$ & $\begin{array}{c}16 \cdot 83 \\
(16 \cdot 87)\end{array}$ & $\begin{array}{c}17 \cdot 76 \\
(17 \cdot 75)\end{array}$ & 14 & $\begin{array}{l}3.14 \\
(298)\end{array}$ \\
\hline $\begin{array}{l}{[\mathrm{Zn}(\text { Cysme })(\text { Hisme })]} \\
{\left[\mathrm{ZnC}_{11} \mathrm{H}_{19} \mathrm{~N}_{4} \mathrm{O}_{4} \mathrm{~S}\right]}\end{array}$ & $\begin{array}{c}35 \cdot 78 \\
(35 \cdot 83)\end{array}$ & $\begin{array}{l}5 \cdot 10 \\
(5 \cdot 15)\end{array}$ & $\begin{array}{c}15 \cdot 19 \\
(15 \cdot 20)\end{array}$ & $\begin{array}{c}17 \cdot 69 \\
(17 \cdot 75)\end{array}$ & 13 & Diamagnetic \\
\hline $\begin{array}{l}\mathrm{Co}(\text { Cysme })(\text { Hisme })] \\
{\left[\mathrm{CoC}_{11} \mathrm{H}_{19} \mathrm{~N}_{4} \mathrm{O}_{4} \mathrm{~S}\right]}\end{array}$ & $\begin{array}{c}36 \cdot 44 \\
(36 \cdot 47)\end{array}$ & $\begin{array}{l}5 \cdot 18 \\
(5 \cdot 24)\end{array}$ & $\begin{array}{c}15 \cdot 43 \\
(15 \cdot 47)\end{array}$ & $\begin{array}{l}(16 \cdot 21) \\
(16 \cdot 28)\end{array}$ & 13 & $\begin{array}{l}3.46 \\
(298)\end{array}$ \\
\hline
\end{tabular}

Table 2. Infrared spectral data of amino acids.

\begin{tabular}{|c|c|c|c|c|c|c|c|c|}
\hline \multirow[b]{2}{*}{ Ligand } & \multicolumn{2}{|c|}{$v\left(\mathrm{NH}_{3}\right)$} & \multicolumn{2}{|c|}{$v\left(\mathrm{COO}^{-}\right)$} & \multirow[b]{2}{*}{$v(\mathrm{~S}-\mathrm{H})$} & \multirow[b]{2}{*}{$v(\mathrm{C}=\mathrm{N})$} & \multirow[b]{2}{*}{$v(\mathrm{C}=\mathrm{O})$} & \multirow[b]{2}{*}{$v(C-O)$} \\
\hline & Asym & Sym & Asym & Sym & & & & \\
\hline $\begin{array}{l}\text { Histidine } \\
{\left[\mathrm{C}_{6} \mathrm{H}_{8} \mathrm{~N}_{3} \mathrm{O}_{2}\right]}\end{array}$ & $3130(m)^{*}$ & $3009(m)$ & $1588 \cdot 8(\mathrm{~m})$ & $1413.7(s)$ & - & $964 \cdot 4(s)$ & - & - \\
\hline $\begin{array}{l}\text { Cysteine } \\
{\left[\mathrm{C}_{3} \mathrm{H}_{5} \mathrm{NO}_{2} \mathrm{~S}\right]}\end{array}$ & $3000(m)$ & $2946(m)$ & $1582 \cdot 1(s)$ & $1404.4(s)$ & $2600(s h)$ & - & - & - \\
\hline $\begin{array}{l}\text { Histidinemethylester } \\
{\left[\mathrm{C}_{7} \mathrm{H}_{11} \mathrm{~N}_{3} \mathrm{O}_{2}\right]}\end{array}$ & $3150(b r)$ & $2983(b r)$ & - & - & - & $958 \cdot 8(s)$ & $1759(s)$ & $1290(s)$ \\
\hline $\begin{array}{l}\text { Cysteinemethnylester } \\
{\left[\mathrm{C}_{4} \mathrm{H}_{8} \mathrm{NO}_{2} \mathrm{~S}\right]}\end{array}$ & $2986(m)$ & $2838(m)$ & - & - & $264(m)$ & - & $1743(s)$ & $1245(s)$ \\
\hline
\end{tabular}

$*_{s}=$ strong; $m=$ medium; $w=$ weak $; s=$ shoulder $; b r=$ broad

$2946 \mathrm{~cm}^{-1}$ were assigned to $\mathrm{vN}-\mathrm{H}$ asymmetric and symmetric stretching vibrations. The peak at $2731 \mathrm{~cm}^{-1}$ was assigned to $\mathrm{vC}-\mathrm{H}$ stretching frequency. The asymmetric and symmetric stretching vibrations of carboxylate group of cysteine were observed at $1582 \mathrm{~cm}^{-1}$ and $1404 \mathrm{~cm}^{-1}$. The peak due to $v S-H$ was observed at $2600 \mathrm{~cm}^{-1}$. The peaks due to $\mathrm{NH}_{3}^{+}$twisting and rocking and $\mathrm{COO}^{-}$wagging frequencies were observed in the range $1200-600 \mathrm{~cm}^{-1}$.

The infrared spectra of mixed ligand complexes involving the above ligands showed characteristic band positions, band shifts and band intensities which can be correlated to bidentate amino acids chelation with metal ions.

As regards the chelation of amino acids, the IR spectra exhibited significant features in $\mathrm{vNH}_{2}$, $\mathrm{vCOO}^{-}$regions. It is worthwhile mentioning here that the free amino acids exist as zwitterions $\left(\mathrm{NH}_{3}^{+}\right.$ $\mathrm{AA} . \mathrm{COO}^{-}$) and the IR spectra of these cannot be compared entirely with those of metal complexes as amino acids in metal complexes do not exist as zwitterions. $^{34}$ Particularly, free amino acids with $\mathrm{NH}_{3}^{+}$functions shows $\mathrm{vNH}_{3}$ in the region of 3130$3030 \mathrm{~cm}^{-1}$. In the complexes, $\mathrm{NH}_{3}^{+}$gets deprotonated and binds to metal through the neutral $\mathrm{NH}_{2}$ group. The transformations of $\mathrm{NH}_{3}^{+}$to $\mathrm{NH}_{2}$ must result in an upward shift in $\mathrm{vNH}_{2}$ compared to free amino acids. At isoelectric point, they must show $\mathrm{vNH}_{2}$ in the region $3500-3300 \mathrm{~cm}^{-1}$. In $\mathbf{1}$ and $\mathbf{2}$ complexes (table 3 ) the IR spectra showed characteristic bands in the region $3300-3000 \mathrm{~cm}^{-1}$ which is lower in comparison with free $\mathrm{NH}_{2}$. Hence, it can be concluded that the nitrogen of the amino group is involved in metal coordination. No shift was observed in the asymmetric and symmetric stretching vibrations of carboxylate groups, this supports the non-involvement of carboxylate groups in metal coordination. The spectra also showed shifting of $v$ imidazole in plane to $1050 \mathrm{~cm}^{-1}$, indicating the coordination of imidazole nitrogen with the metal. The peak due to $v \mathrm{~S}-\mathrm{H}$ is lost in the spectra of the mixed ligand complexes, due to deprotanation of the $\mathrm{S}-\mathrm{H}$ group on binding 
Table 3. Infrared spectral data of mixed ligand complexes of $\mathrm{Zn}(\mathrm{II})$ and $\mathrm{Co}(\mathrm{II})$ with amino acids.

\begin{tabular}{|c|c|c|c|c|c|c|c|c|c|c|}
\hline \multirow[b]{2}{*}{ Ligand } & \multicolumn{2}{|c|}{$v\left(\mathrm{NH}_{3}\right)$} & \multicolumn{2}{|c|}{$v\left(\mathrm{COO}^{-}\right)$} & \multirow[b]{2}{*}{$v(\mathrm{~S}-\mathrm{H})$} & \multirow[b]{2}{*}{$v(C=N)$} & \multirow[b]{2}{*}{$v(\mathrm{C}=\mathrm{O})$} & \multirow[b]{2}{*}{$v(\mathrm{C}-\mathrm{O})$} & \multicolumn{2}{|c|}{ Non-lignad bands } \\
\hline & Asym & Sym & Asym & Sym & & & & & $v(\mathrm{M}-\mathrm{N})$ & $v(\mathrm{M}-\mathrm{S})$ \\
\hline $\begin{array}{l}{[\mathrm{Zn}(\mathrm{Cys})(\mathrm{His})]} \\
{\left[\mathrm{ZnC}_{9} \mathrm{H}_{13} \mathrm{~N}_{4} \mathrm{O}_{4} \mathrm{~S}\right]}\end{array}$ & $3256(b r)^{*}$ & $3150(b r)$ & $1589(s)$ & $1400(m)$ & - & $1062(s)$ & - & - & $500(m)$ & $400(m)$ \\
\hline $\begin{array}{l}{[\mathrm{Co}(\mathrm{Cys})(\mathrm{His})]} \\
{\left[\mathrm{CoC}_{9} \mathrm{H}_{13} \mathrm{~N}_{4} \mathrm{O}_{4} \mathrm{~S}\right]}\end{array}$ & $3227(b r)$ & $3120(b r)$ & $1612(s)$ & $1383(s)$ & - & $1030(w)$ & - & - & $470(m)$ & $410(w)$ \\
\hline $\begin{array}{l}{[\mathrm{Zn}(\text { Cysme })(\text { Hisme })]} \\
{\left[\mathrm{ZnC}_{11} \mathrm{H}_{19} \mathrm{~N}_{4} \mathrm{O}_{4} \mathrm{~S}\right]}\end{array}$ & $3308(m)$ & $2931(m)$ & - & - & - & $1069(m)$ & $1740(w)$ & $1240(m)$ & $480(m)$ & $400(w)$ \\
\hline $\begin{array}{l}{[\mathrm{Co}(\mathrm{Cysme})(\text { Hisme })]} \\
{\left[\mathrm{CoC}_{11} \mathrm{H}_{19} \mathrm{~N}_{4} \mathrm{O}_{4} \mathrm{~S}\right.}\end{array}$ & $3240(m)$ & $2931(m)$ & - & - & - & $1090(\mathrm{~m})$ & $1740(w)$ & $1240(m)$ & $479(m)$ & $400(w)$ \\
\hline
\end{tabular}

$*_{s}=$ strong; $m=$ medium; $w=$ weak; $s h=$ shoulder $b r=$ broad

with the metal. The spectra did not show any broad band in the range $3400 \mathrm{~cm}^{-1}$ to $3100 \mathrm{~cm}^{-1}$, indicating the non coordination of water molecules. Other low intensity bands observed in the far IR region in the range $460-500 \mathrm{~cm}^{-1}$ were assigned to $\mathrm{v}(\mathrm{M}-\mathrm{N})$ stretching and $400 \mathrm{~cm}^{-1}$ to $\mathrm{v}(\mathrm{M}-\mathrm{S})$ stretching vibrations. The peak due to $v(\mathrm{M}-\mathrm{Cl})$ at $\sim 280 \mathrm{~cm}^{-1}$ was not observed, indicating the non coordination of chloride in complexes. Thus from the IR spectra of the mixed ligand complexes it is clear that histidine binds to metal ions through imidazole and amino nitrogens and cysteine binds through thiol sulphur and amino nitrogen.

The IR spectrum (table 2) of esters of amino acids exhibits significant features in $\mathrm{vNH}_{3}$ and $v \mathrm{C}=\mathrm{O}$ regions. A broad, strong $\mathrm{NH}_{3}^{+}$stretching band in the $3100-2600 \mathrm{~cm}^{-1}$ region is observed both in the spectrum of histidinemethylester and cysteinemethylester ligands. Multiple combination and overtone bands extend the absorption to about $2000 \mathrm{~cm}^{-1}$. This overtone region usually contains a prominent band near $2222-2000 \mathrm{~cm}^{-1}$ assigned to a combination of the asymmetrical $\mathrm{NH}_{3}^{+}$bending vibration and a torsional oscillation of the $\mathrm{NH}_{3}^{+}$group that occurs near $500 \mathrm{~cm}^{-1}$. A weak asymmetric $\mathrm{NH}_{3}^{+}$bending band near 1660 $1610 \mathrm{~cm}^{-1}$ and a fairly strong symmetrical bending band near $1550-1485 \mathrm{~cm}^{-1}$ are observed in the spectra of both ligands. A strong band at $1220-1190 \mathrm{~cm}^{-1}$ arises due to $\mathrm{C}-\mathrm{C}-\mathrm{O}$ stretching and a strong band in the range $1725-1730 \mathrm{~cm}^{-1}$ is assigned to ester carbonyl group. In addition to these bands histidinemethylester has a peak at $958.8 \mathrm{~cm}^{-1}$ due to $v$ imidazole in plane and cysteinemethylester has a peak at $2641.4 \mathrm{~cm}^{-1}$, due to $v \mathrm{~S}-\mathrm{H}$ stretching.

In the ternary complexes, the IR spectra (table 3) showed characteristic bands in the region 3300-
$3000 \mathrm{~cm}^{-1}$ which is lower in comparison with free $v \mathrm{NH}_{2}\left(3500-3300 \mathrm{~cm}^{-1}\right)$. Hence, it can be concluded that the nitrogen of the amino group is involved in coordination with metal. This is also confirmed by the absence of a peak at $2000 \mathrm{~cm}^{-1}$ in the spectrum of metal complexes, due to binding of $\mathrm{NH}_{2}$ to the metal ion. No shift was observed in the stretching vibration of ester carbonyl group, this supports the non involvement of ester group in metal coordination. The spectra also showed shifting of $v$ imidazole band to $\sim 1050 \mathrm{~cm}^{-1}$, indicating the coordination of imidazole nitrogen with the metal. The peak due to vS-H was not seen in the spectra of the mixed ligand complexes, due to deprotonation of the $\mathrm{S}-\mathrm{H}$ group on binding with the metal. The spectra did not show a broad band in the range $3400 \mathrm{~cm}^{-1}$ to $3100 \mathrm{~cm}^{-1}$, indicating the non-coordination of water molecules. Other low intensity bands observed in far IR region in the range $480-500 \mathrm{~cm}^{-1}$ were assigned to $v(\mathrm{M}-\mathrm{N})$ stretching and at $400 \mathrm{~cm}^{-1}$ to $v(\mathrm{M}-\mathrm{S})$ stretching vibrations. The peak due to $v(\mathrm{M}-\mathrm{Cl})$ at $\sim 280 \mathrm{~cm}^{-1}$ was not observed, indicating the non-coordination of chloride ions in the complexes. Thus from IR spectra of the mixed ligand complexes it is clear that histidinemethylester binds to metal ions with imidazole and amino nitrogens and cysteinemethylester binds through the thiol sulphur and the amino nitrogen atom.

\section{$3.2{ }^{l} H$ NMR spectra}

The ${ }^{1} \mathrm{H}$ NMR assignments at $\mathrm{pH} 4-5$ for free ligands and $[\mathrm{Zn}(\mathrm{Cys})(\mathrm{His})]^{-}(\mathbf{1})$ complex are summarized in table 4 . They were identified with the help of literature data. ${ }^{35}$ In the ${ }^{1} \mathrm{H}$ NMR spectra of His, the chemical shifts at $4.02 \mathrm{ppm}, 3.29 \mathrm{ppm}, 6.97 \mathrm{ppm}$ and $7.71 \mathrm{ppm}$ have been assigned to the resonances due to $\mathrm{CH}(\alpha)$, 
Table 4. ${ }^{1} \mathrm{H}-\mathrm{NMR}$ chemical shifts at $\mathrm{pH}=4-5$ of cysteine and histidine in the absence and presence of $\mathrm{Zn}(\mathrm{II})$.

\begin{tabular}{lcccccc}
\hline System & $\mathrm{CH}(\alpha)$ & $\mathrm{CH}_{2}(\beta)$ & $\mathrm{CH}(\delta)$ & $\mathrm{CH}(\varepsilon)$ & $\mathrm{CH}_{2}\left(\beta^{\prime}\right)$ & $\mathrm{CH}\left(\alpha^{\prime}\right)$ \\
\hline Histidine & 3.98 & 3.29 & $7 \cdot 01$ & $7 \cdot 71$ & - & - \\
Cysteine & - & - & - & - & $3 \cdot 16$ & 4.06 \\
{$[\text { Zn }(\text { Cys })(\mathrm{His})]^{-}$} & 3.6 & 3.2 & $7 \cdot 3$ & 8.55 & 2.98 & 3.3 \\
\hline
\end{tabular}

Table 5. ${ }^{1} \mathrm{H}-\mathrm{NMR}$ chemical shifts at $\mathrm{pH}=4-5$ of cysteinemethylester and histidinemethylester in the absence and presence of $\mathrm{Zn}(\mathrm{II})$.

\begin{tabular}{lccccccc}
\hline System & $\mathrm{CH}(\alpha)$ & $\mathrm{CH}_{2}(\beta)$ & $\mathrm{CH}(\delta)$ & $\mathrm{CH}(\varepsilon)$ & $\mathrm{OCH}_{3}$ & $\mathrm{CH}_{2}\left(\beta^{\prime}\right)$ & $\mathrm{CH}\left(\alpha^{\prime}\right)$ \\
\hline Histidinemethylester & 4.30 & 4.04 & $7 \cdot 18$ & 8.05 & 3.38 & - & - \\
Cysteinemethylester & - & - & - & - & 3.38 & 3.28 & $3 \cdot 10$ \\
[Zn(Cysme)(Hisme) $]^{+}$ & 4.28 & 3.40 & 7.40 & 8.62 & 3.38 & 3.18 & 3.03 \\
\hline
\end{tabular}

$\mathrm{CH}_{2}(\beta), \mathrm{CH}(\delta)$ and $\mathrm{CH}(\varepsilon)$ respectively. In the ${ }^{1} \mathrm{H}$ NMR spectra of Cys, the chemical shifts at $3.16 \mathrm{ppm}$ and $4.06 \mathrm{ppm}$ have been assigned to the resonances due to $\mathrm{CH}\left(\alpha^{\prime}\right)$, and $\mathrm{CH}_{2}\left(\beta^{\prime}\right)$ respectively. In the ${ }^{1} \mathrm{H}$ NMR spectra of the 1 complex, the chemical shifts of histidine corresponding to $\mathrm{CH}(\varepsilon)$ and $\mathrm{CH}(\delta)$ were shifted downfield and since zinc causes deprotonation of $\mathrm{NH}_{3}$ protons on binding, the $\mathrm{CH}(\alpha)$ resonance was shifted upfield. Thus, the spectra confirm the involvement of imidazole and amino nitrogens resulting in a bidentate mode in metal coordination. In cysteine $\mathrm{CH}_{2}\left(\beta^{\prime}\right)$ and $\mathrm{CH}\left(\alpha^{\prime}\right)$ resonances were shifted upfield in the metal complex, confirming the involvement of thiol sulphur and amino nitrogen atoms in zinc coordination.

The ${ }^{1} \mathrm{H}$ NMR assignments at $\mathrm{pH}$ 4-5 for free ligands and $[\mathrm{Zn}(\text { Cysme })(\text { Hisme })]^{+}(\mathbf{3})$ complex are summarized in table 5. In the ${ }^{1} \mathrm{H}$ NMR spectra of Hisme, the chemical shifts at $4.30 \mathrm{ppm}, 4.04 \mathrm{ppm}$, $7.18 \mathrm{ppm}, 8.05 \mathrm{ppm}$ and $3.38 \mathrm{ppm}$ have been assigned to the resonances due to $\mathrm{CH}(\alpha), \mathrm{CH}_{2}(\beta), \mathrm{CH}(\delta)$, $\mathrm{CH}(\varepsilon)$ and $\mathrm{OCH}_{3}$ respectively. In the ${ }^{1} \mathrm{H}$ NMR spectra of Cysme, the chemical shifts at $3 \cdot 10 \mathrm{ppm}, 3.28 \mathrm{ppm}$ and $3.38 \mathrm{ppm}$ have been assigned to the resonances due to $\mathrm{CH}\left(\alpha^{\prime}\right), \mathrm{CH}_{2}\left(\beta^{\prime}\right)$ and $\mathrm{OCH}_{3}$ respectively. In the ${ }^{1} \mathrm{H}$ NMR spectra of the $\mathbf{3}$ complex, the chemical shifts of Hisme corresponding to $\mathrm{CH}(\varepsilon)$ and $\mathrm{CH}(\delta)$ were shifted downfield and since zinc causes deprotonation of $\mathrm{NH}_{3}$ protons on binding, the $\mathrm{CH}(\alpha)$ resonance was shifted upfield. Thus, the spectra confirm the involvement of imidazole and amino nitrogens in metal coordination resulting in a bidentate mode in metal coordination. In Cysme, $\mathrm{CH}_{2}\left(\beta^{\prime}\right)$ and $\mathrm{CH}\left(\alpha^{\prime}\right)$ resonances were shifted upfield in the metal complex, confirming the involvement of thiol sulphur and amino nitrogen atoms in zinc coordination. Thus, the spectra suggest bidentate coordination of these ligands resulting in tetra coordination around zinc.

\subsection{Reflectance spectra}

The reflectance spectra of the complexes $\mathbf{1}$ and $\mathbf{2}$ showed multiple bands at $28820 \mathrm{~cm}^{-1}, 32790 \mathrm{~cm}^{-1}$ and $35210 \mathrm{~cm}^{-1}$, which were assigned to charge transfer (CT) bands in the complexes. However, an additional band at $15380 \mathrm{~cm}^{-1}$ was observed in $[\mathrm{Co}(\mathrm{Cys})(\mathrm{His})]^{-}$complex (figure 1a), which was assigned to $d-d$ transition, ${ }^{4} A_{2} \rightarrow{ }^{4} T_{1}(P)$. Accordingly, tetrahedral geometry was proposed for the cobalt complex.

The reflectance spectra of the complexes $\mathbf{3}$ and $\mathbf{4}$ showed multiple bands at $28820 \mathrm{~cm}^{-1}, 32790 \mathrm{~cm}^{-1}$ and $35340 \mathrm{~cm}^{-1}$, which were assigned to charge transfer (CT) bands in the complexes. However, an additional band at $15580 \mathrm{~cm}^{-1}$ was observed in $[\mathrm{Co}(\text { Cysme })(\text { Hisme })]^{+}$complex (figure $\left.1 \mathrm{~b}\right)$, which was assigned to $d-d$ transition, ${ }^{4} A_{2} \rightarrow{ }^{4} T_{1}(P)$. Accordingly, tetrahedral geometry was proposed for the cobalt complex.

\subsection{Magnetic susceptibility}

Magnetic susceptibility are recorded at room temperature on Faraday balance and the magnetic moments of 3.14 BM for 2 and 3.46 BM for 4 complexes suggest that the central metal ion is in high spin configuration. For tetrahedral geometry the magnetic value for spin only moment is $3.89 \mathrm{BM}$. The values 

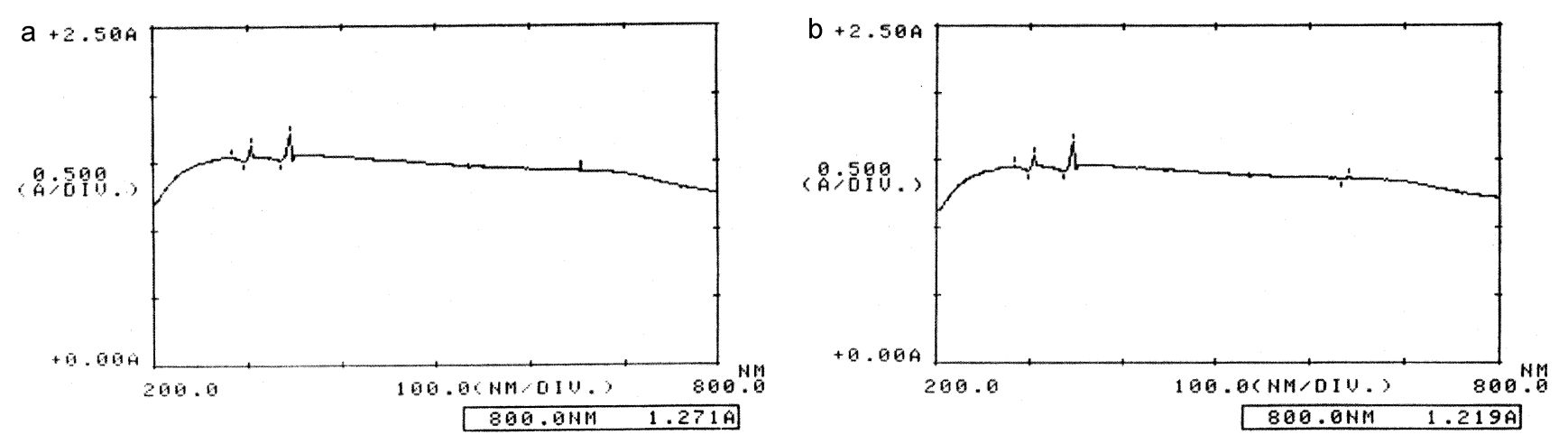

Figure 1. Reflectance spectra of (a) $[\mathrm{Co}(\mathrm{Cys})(\mathrm{His})]^{-}$(b) $[\mathrm{Co}(\mathrm{Cysme})(\mathrm{Hisme})]^{+}$.
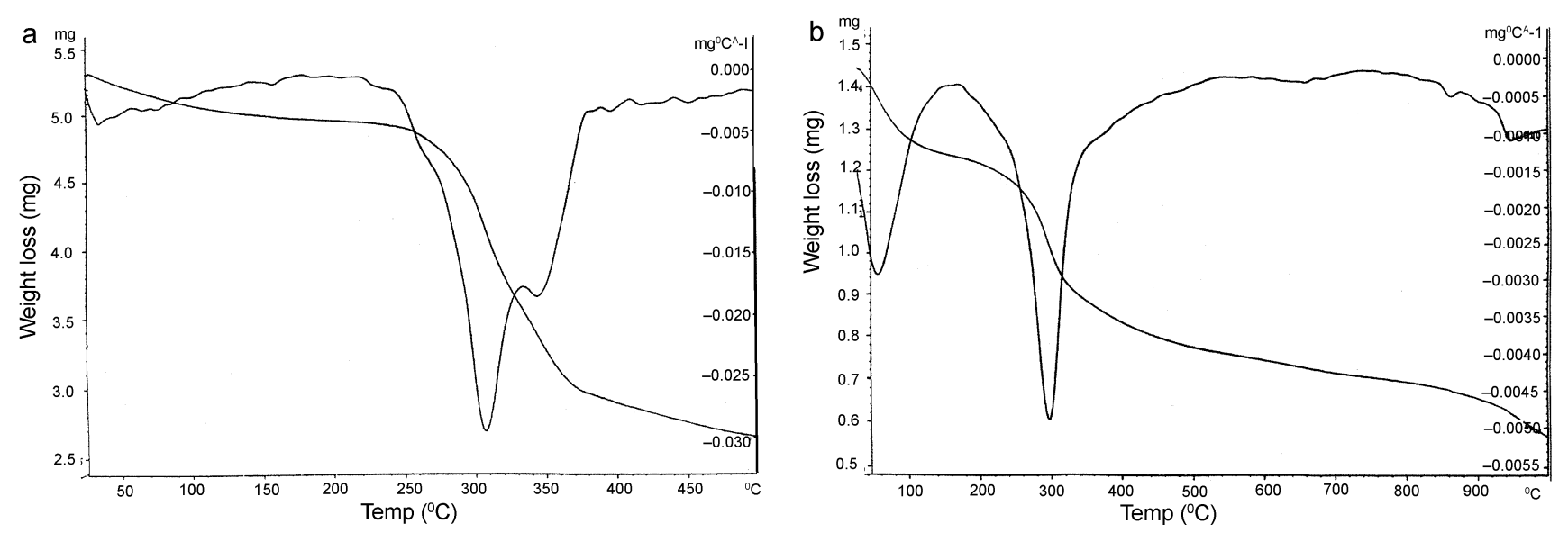

Figure 2. TGA curve of (a) $[\mathrm{Zn}(\mathrm{Cys})(\mathrm{His})]^{-}$and (b) $[\mathrm{Co}(\mathrm{Cys})(\mathrm{His})]^{-}$.

of 3.14 BM and 3.46 BM for the above complexes confirm the tetrahedral geometry.

\subsection{Thermogravimetric analysis}

The TGA curve of $\mathbf{1}$ complex (figure 2a) showed the absence of water molecules, as sudden weight loss was observed at $300^{\circ} \mathrm{C}$. The total weight loss was $50 \%$. The weight loss at $447^{\circ} \mathrm{C}$ was $47.9 \%$, which corresponds to a weight loss of molecular weight 160 units. Similarly, the TGA curve of 2 complex (figure 2b) showed absence of water molecules and the total $\%$ weight loss is $60.73 \%$, and the weight loss at $891^{\circ} \mathrm{C}$ was $54.24 \%$, which corresponds to a weight loss of molecular weight of 179 units. The TGA curve of $\mathbf{3}$ complex showed sudden weight loss at $300^{\circ} \mathrm{C}$, indicating the absence of water molecules in the coordination sphere of the complex. The total weight loss was $77.48 \%$ and the weight loss at $891{ }^{\circ} \mathrm{C}$ was $70 \cdot 15 \%$, which corresponds to a weight loss of molecular weight 257 units. Similarly, the TGA curve of $\mathbf{4}$ complex showed the absence of water molecules and the total weight loss was $58.83 \%$, and the weight loss at $891{ }^{\circ} \mathrm{C}$ was $53.23 \%$, which corresponds to a weight loss of molecular weight of 193 units, implied in a $1: 1: 1$ complex in accordance with the analytical data.

The thermogravimetric analysis (TGA) provides authentic information regarding the absence of water molecules in the coordination sphere of the complex. Further, the electronic, magnetic, IR and NMR spectral data confirm tetrahedral geometry for all the complexes studied. Based on these conclusions, the structure 2 is proposed for these ternary complexes.

\subsection{FAB mass spectra}

As an additional support for the above conclusions, the FAB mass spectra of the complexes were recorded (figures 3 and 4). In the FAB mass spectrum (figure 3a) of complex $\mathbf{1}$, the molecular ion peak was 

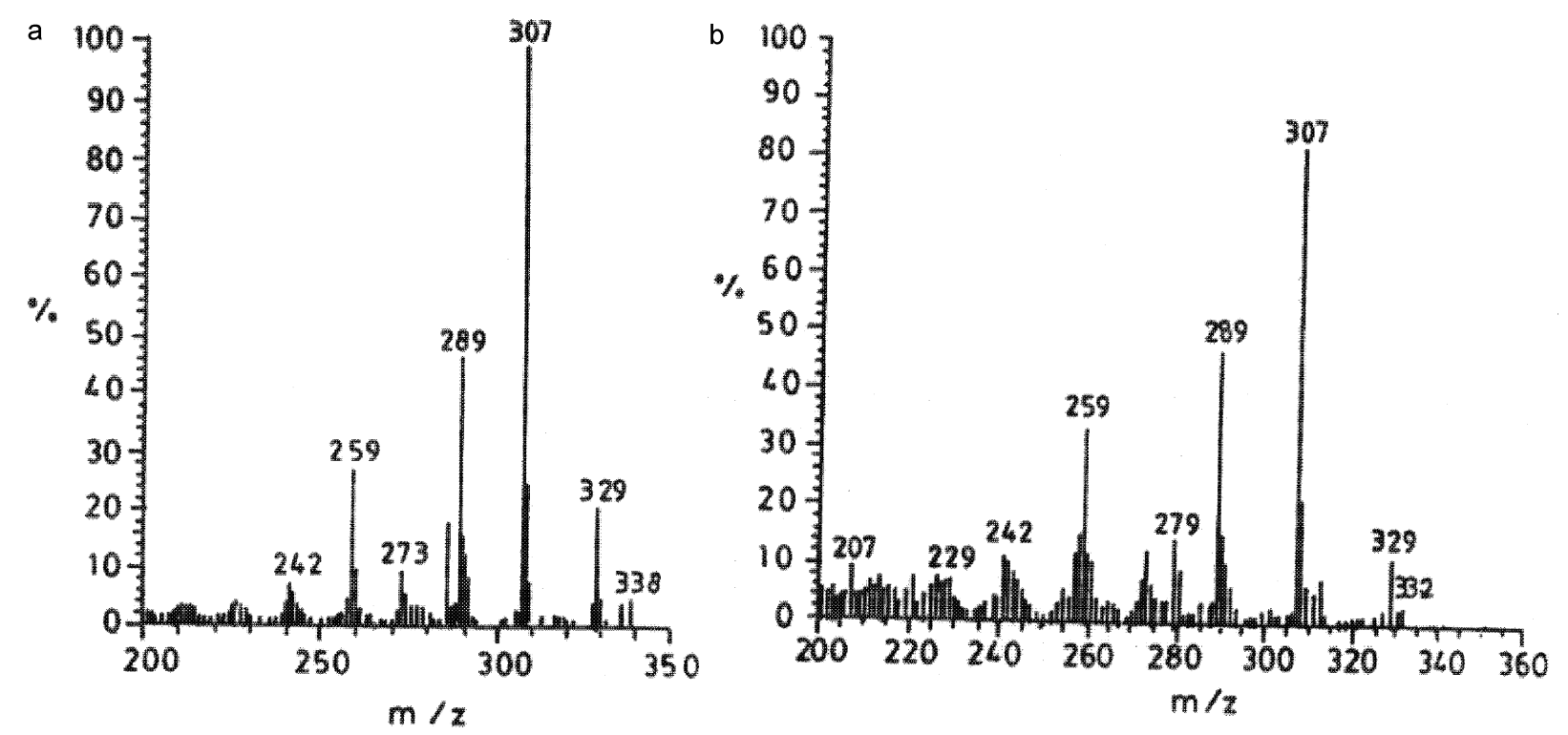

Figure 3. FAB mass spectra of (a) $[\mathrm{Zn}(\mathrm{Cys})(\mathrm{His})]^{-}$and (b) $[\mathrm{Co}(\mathrm{Cys})(\mathrm{His})]^{-}$.
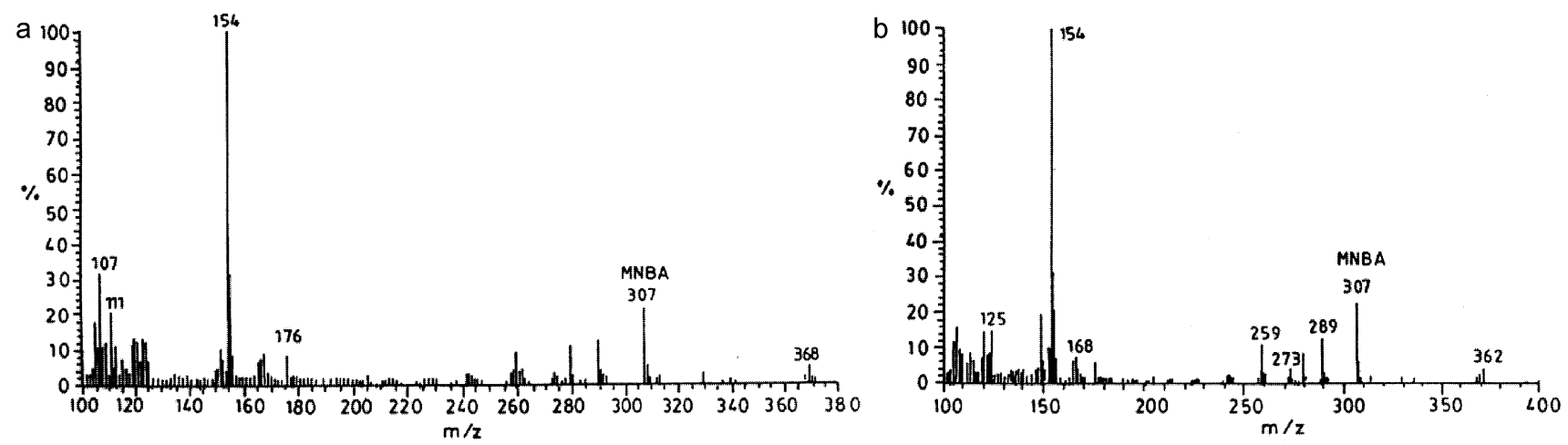

Figure 4. $\mathrm{FAB}$ mass spectra of (a) $[\mathrm{Zn}(\mathrm{Cysme})(\text { Hisme })]^{+}$and (b) $[\mathrm{Co}(\mathrm{Cysme})(\text { Hisme })]^{+}$.

observed at $m / z 338$, which is in agreement with the molecular weight (338) of the proposed structure. The spectrum showed a peak at $m / z 307$, which is assigned to $m$-nitro benzyl alcohol. The molecular ion loses $\mathrm{S}$ and $\mathrm{NH}_{2}$ giving an ion at $m / z$ 289. This ion loses one more $\mathrm{NH}_{2}$ giving an ion at $\mathrm{m} / \mathrm{z} 273$, which further loses $\mathrm{CH}_{2}$ giving an ion at $\mathrm{m} / z 259$. The molecular ion also loses the imidazole ring $\mathrm{CH}_{2}$, $\mathrm{CH}$ giving a peak at $m / z 242$.

In the FAB mass spectrum (figure $3 b$ ) of complex 2, the molecular ion peak was observed at $\mathrm{m} / \mathrm{z} 332$, which is in agreement with the molecular weight (332) of the proposed structure. The spectrum showed a peak at $m / z 307$, which is assigned to $m$-nitro benzyl alcohol. The molecular ion loses $\mathrm{COO}^{-}$giving an ion at $\mathrm{m} / \mathrm{z}$ 289. The molecular ion also loses $\mathrm{NH}_{2}-\mathrm{CH}-\mathrm{COO}^{-}$giving an ion at $m / z 259$, which fur- ther loses one more $\mathrm{NH}_{2}$ giving an ion at $\mathrm{m} / \mathrm{z} 242$ and this ion loses $\mathrm{CH}$ giving an ion at $m / z 229$.

In the FAB mass spectrum (figure $4 \mathrm{a}$ ) of complex 3, the molecular ion peak was observed at $\mathrm{m} / \mathrm{z} 368$, which is in agreement with the molecular weight (368) of the proposed structure. The spectrum shows peaks at $m / z, 307$ and $m / z$ 154, which are assigned to $m$-nitro benzyl alcohol. The molecular ion loses histidinemethylester, $\mathrm{NH}_{2}-\mathrm{CH}-\mathrm{COOCH}_{3}$ giving an ion at $\mathrm{m} / \mathrm{z} 111$. The molecular ion loses imidazole ring, two moles of $\left(\mathrm{NH}_{2}-\mathrm{CH}-\mathrm{COOCH}_{3}\right)$ and $\mathrm{CH}_{2}$ giving an ion at $m / z 176$.

In the FAB mass spectrum (figure $4 \mathrm{~b}$ ) of complex 4, the molecular ion peak was observed at $\mathrm{m} / \mathrm{z}, 362$, which is in agreement with the molecular weight (362) of the proposed structure. The spectrum showed peaks at $\mathrm{m} / z, 307$ and $\mathrm{m} / \mathrm{z}$ 154, which are assigned to 


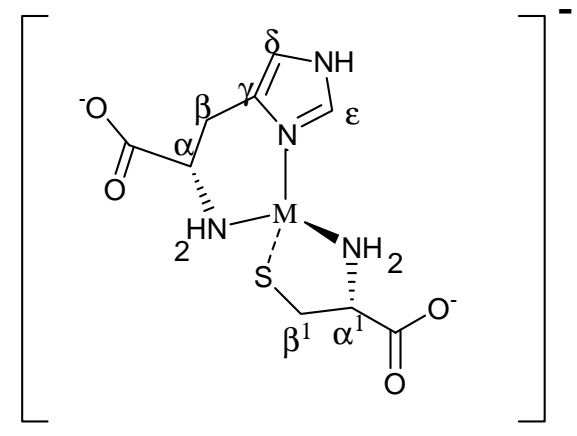

Structure 1. Geometry of $M=\operatorname{Zn}$ (1) and $M=C o$ (2) complexes.

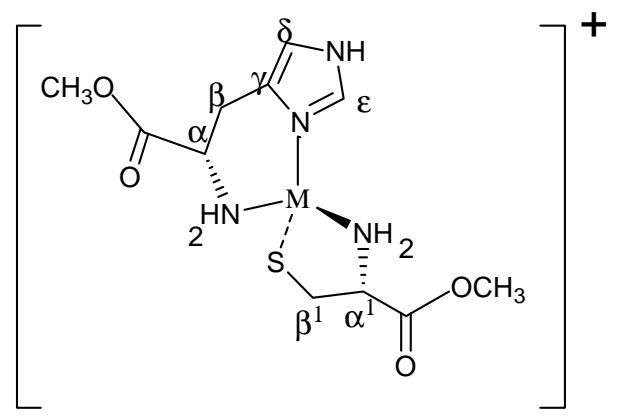

Structure 2. Geometry of $M=\operatorname{Zn}$ (3) and $M=$ Co (4) complexes.

$m$-nitro benzyl alcohol. The molecular ion loses $\mathrm{CH}-\mathrm{COOCH}_{3}$ giving an ion at $m / z$ 289. This ion loses $\mathrm{NH}_{2}$ giving an ion at $\mathrm{m} / \mathrm{z}$ 273, which further loses $\mathrm{CH}_{2}$ giving ion $\mathrm{m} / z$ 259. The molecular ion also loses cysteinemethylester, $\mathrm{COOCH}_{3}$ giving a peak at $\mathrm{m} / \mathrm{z}$ 168, which further loses $\mathrm{NH}_{2}, \mathrm{CH}, \mathrm{CH}_{2}$ giving an ion at $m / z 125$.

Thus the FAB mass spectra further strengthens the proposed structures for $[\mathrm{M}(\mathrm{Cys})(\mathrm{His})]^{-}$and $[\mathrm{M}$ (Cysme)(Hisme) $]^{+}$complexes (structures 1 and 2).

\section{Acknowledgements}

Financial support from Department of Science and Technology, New Delhi is gratefully acknowledged.

\section{References}

1. Bertini I, Luchinat C, Maret W and Zeppezauer $\mathrm{M}$ (eds) 1986 Zinc enzymes (Boston: Birkhaused)

2. Christianson D W 1991 Adv. Protein Chem. 42281

3. Vallee B L and Auld D S 1993 Acc. Chem. Res. 26 5433
4. Burger K (ed.) 1990 Biocoordination chemistry: Coordination equilibria in biologically active systems (New York: Ellis Horwood)

5. Rombach M, Gelinsky M and Vahrenkamp H 2002 Inorg. Chim. Acta 33425

6. Ranganathan S, Jayaraman N and Roy R 1992 Tetrahedron 48931

7. Nagaoka M and Sugiura Y 2000 J. Inorg. Biochem. 8257

8. Reddy P R, Mohan S M and Rao K S 2004 Indian J. Chem. A43 2329

9. Ranganathan S, Jayaraman N and Chatterji D 1997 Biopolymers 41407

10. Parkin G 2004 Chem. Rev. 104699

11. Gelinsky M and Vahrenkamp H 2002 Eur. J. Inorg. Chem. 2458

12. Boerzel H, Koeckert M, Bu W, Spingler B and Lippard S J 2003 Inorg. Chem. 421604

13. Spiro T (ed.) 1983 Zinc enzymes (New York: Wiley)

14. Sigel H (ed.) 1983 Metal ions in biological systems: Zinc and its role in biology and nutrition (New York: Marcel Dekker) vol. 15

15. Harrison P (ed.) 1985 Metalloproteins, metal proteins with non-redox roles (Weinheim: $\mathrm{VCH}$ ) part 2

16. Lin Q, Barbas C F and Schultz P G 2003 J. Am. Chem. Soc. 125612

17. Pauletich N P and Pabo C O 1991 Science 252809

18. Lee M S, Gippert G P, Soman K V, Case D A and Wright P E 1989 Science 245635

19. Williams R J P 1987 Polyhedron 661

20. Berg J 1986 Science 232485

21. Johnston M 1987 Nature (London) 328353

22. Miller J, Malachaln A D and Klug A 1985 EMBO J. 41609

23. Klug A and Rhodes R 1987 Trends Biochem Sci. 12 464

24. Fairall L, Rhodes D and Klug A 1986 J. Mol. Biol. 192577

25. Dikan G P, Fairall L and Klug A 1986 Nature (London) 324698

26. Brown R S, Sander C and Argos P 1985 FEBS Lett. 186271

27. Brown R S and Argos P 1986 Nature (London) 324215

28. Wingender E and Seifart K H 1987 Angew. Chem., Int. Ed. Engl. 26218

29. Chang S, Karambelkar V V, Sommer R D, Rheingold A L and Goldberg D P 2002 Inorg. Chem. 41239

30. Reddy P R, Reddy A M and Radhika M 1998 Indian J. Chem. A37 775

31. Figgis B N and Lewis J 1967 Modern coordination chemistry (eds) J Lewis and R C Wilkinson (New York: Wiley-Inter-Science) p. 403

32. Geary W J 1971 J. Coord. Chem. Rev. 781

33. Nokamoto K 1970 Infrared spectra of inorganic and coordination compounds (New York: Wiley InterScience)

34. Bellamy L J 1975 The infrared spectra of complex molecules, 3rd edn (London: Chapman and Hall)

35. Amparo C, Virtudes M, Eiles M and Carles M 1992 J. Inorg. Biochem. 48135 